OPEN ACCESS

Edited by:

Enikö Kallay,

Medical University of Vienna, Austria

Reviewed by:

Emmanuel Modesto Awumey, North Carolina Central University, USA

Fadil Hannan,

University of Liverpool, UK

*Correspondence:

Geoffrey N. Hendy

geoffrey.hendy@mcgill.ca

Specialty section:

This article was submitted to Integrative Physiology, a section of the journal

Frontiers in Physiology

Received: 29 June 2016

Accepted: 23 August 2016 Published: 13 September 2016

Citation:

Hendy GN and Canaff L (2016) Calcium-Sensing Receptor Gene: Regulation of Expression Front. Physiol. 7:394 doi: 10.3389/fphys.2016.00394

\section{Calcium-Sensing Receptor Gene: Regulation of Expression}

\author{
Geoffrey N. Hendy* and Lucie Canaff
}

Experimental Therapeutics and Metabolism, McGill University Health Centre-Research Institute, Departments of Medicine, Physiology, and Human Genetics, McGill University, Montréal, QC, Canada

The human calcium-sensing receptor gene (CASR) has 8 exons, and localizes to chromosome 3q. Exons $1 \mathrm{~A}$ and $1 \mathrm{~B}$ encode alternative $5^{\prime}$-untranslated regions (UTRs) that splice to exon 2 encoding the AUG initiation codon. Exons 2-7 encode the CaSR protein of 1078 amino acids. Promoter P1 has TATA and CCAAT boxes upstream of exon $1 \mathrm{~A}$, and promoter $\mathrm{P} 2$ has Sp1/3 motifs at the start site of exon 1B. Exon $1 \mathrm{~A}$ transcripts from the $\mathrm{P} 1$ promoter are reduced in parathyroid tumors and colon carcinomas. Studies of colon carcinomas and neuroblastomas have emphasized the importance of epigenetic changes - promoter methylation of the GC-rich P2 promoter, histone acetylation - as well as involvement of microRNAs in bringing about CASR gene silencing and reduced CaSR expression. Functional cis-elements in the CASR promoters responsive to 1,25-dihydroxyvitamin $\mathrm{D}\left[1,25(\mathrm{OH})_{2} \mathrm{D}\right]$, proinflammatory cytokines, and the transcription factor glial cells missing-2 (GCM2) have been characterized. Reduced levels of CaSR and reduced responsiveness to active vitamin D in parathyroid neoplasia and colon carcinoma may blunt the "tumor suppressor" activity of the CaSR. The hypocalcemia of critically ill patients with burn injury or sepsis is associated with CASR gene upregulation by TNF-alpha and IL-1beta via kappaB elements, and by IL-6 via Stat $1 / 3$ and Sp1/3 elements in the CASR gene promoters, respectively. The CASR is transactivated by GCM2 - the expression of which is essential for parathyroid gland development. Hyperactive forms of GCM2 may contribute to later parathyroid hyperactivity or tumorigenesis. The expression of the CaSR - the calciostat - is regulated physiologically and pathophysiologically at the gene level.

Keywords: gene, alternative transcripts, transcription, vitamin D, proinflammatory cytokines, glial cells missing-2, DNA methylation, microRNA

\section{THE CASR GENE}

The single-copy CASR gene that maps to human 3q13.3-21 encodes a Class C G protein-coupled receptor family member (Pollak et al., 1993; Janicic et al., 1995). The T-cell antigen CD86 gene lies upstream and the cysteine protease inhibitor CSTA gene downstream of the CASR gene and all are transcribed in the same $5^{\prime}$ to $3^{\prime}$ direction.

The CASR gene has eight exons and spans $\sim 100-\mathrm{kb}$ (Yun et al., 2007) (Figure 1). Exons 2 to 7 encode the CaSR protein of 1078 aa (GenBank \#U20759). Two different polyadenylation signal sequences within exon 7 may be used, to generate either a short (177-nucleotide) or a long (1304nucleotide) 3'-untranslated region (UTR) (Aida et al., 1995; Garrett et al., 1995). Exon 2 encodes 242 nucleotides of the $5^{\prime}$-UTR upstream of the ATG translation initiation codon. Exons 1A and 


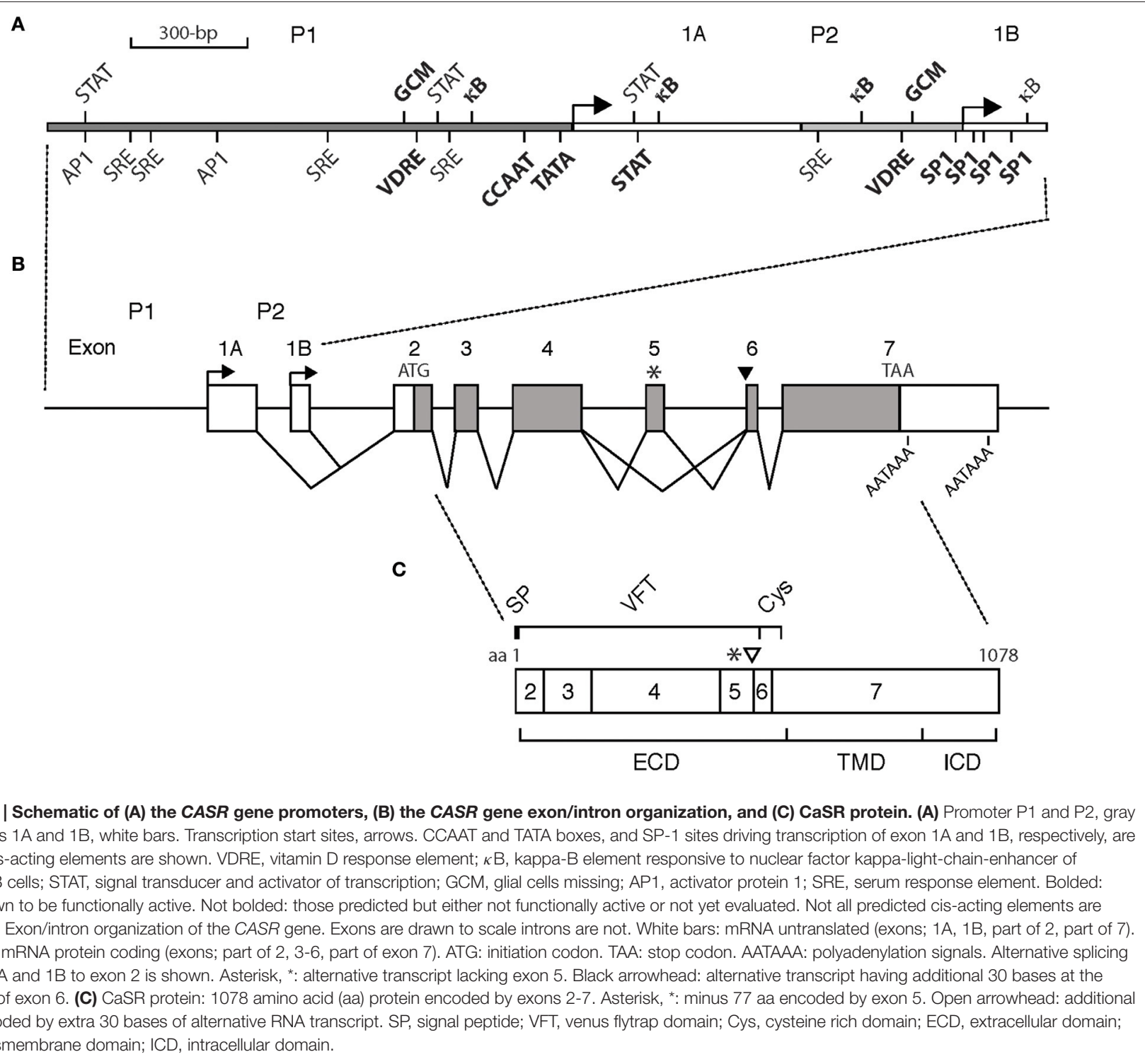

$1 \mathrm{~B}$ encode alternative $5^{\prime}$-UTRs that splice to a common segment encoded by exon 2 (Garrett et al., 1995; Chikatsu et al., 2000).

This organization of exons, conserved around primary protein domains, is first seen in aquatic vertebrates (Naito et al., 1998). With diversification from the teleost fishes to tetrapods, mammals, and primates, the evolutionary changes have been greatest in the $5^{\prime}$ and $3^{\prime}$ domains. While overall exonic structure is preserved a striking increase in intron size has occurred from teleost fish to higher species (Loretz, 2008). Linkage disequilibrium analysis across the human gene shows a central haploblock extending from exon 2 to 7 that is distinct from separate haploblocks for genetic variants in the $5^{\prime}$ and $3^{\prime}$ flanking regions (Yun et al., 2007).

Thus, the mouse, rat and human genes are organized in a similar manner. Both rodent genes comprise at least 7 exons and the translational start site is in exon 2. Alignment of expressed sequence tags (ESTs) and cloned rodent cDNAs reveal that, just like the human CASR gene, mouse and rat CASR genes have at least 2 distinct $5^{\prime} \mathrm{UTR}$ (Exons $1 \mathrm{~A}$ and $1 \mathrm{~B}$ ), suggesting the presence of at least 2 promoters. The mouse and rat CASR genes share $>85 \%$ nucleotide identity (exons and introns) and $40 \%$ with the human CASR. The VDREs and $\mathrm{\kappa B}$ elements (see below) that we have characterized in our studies of the human CASR gene promoters are conserved in the rodent Casr promoters.

\section{Alternative Transcripts}

The CASR gene is highly expressed in the parathyroid gland and renal tubule (Brown et al., 1993). However, the gene is widely expressed at lower levels in other tissues, for example in liver (Canaff et al., 2001), bone (Goltzman and Hendy, 2015) and in lung, breast, placenta, vasculature and gut (Brennan et al., 2013). Several alternative transcripts have been identified, raising the question of their function and regulation of their expression. 
Coexistence of transcripts encoding the same 1078 amino acid protein in human parathyroid but different $5^{\prime}$ UTRs suggested alternative splicing (Garrett et al., 1995). Moreover, the transcripts may have either a short or long 3' UTR. One low abundance transcript encodes an additional 10 amino acid stretch inserted after amino acid 536 in the exodomain (GenBank \#U20760) but does not alter CaSR function (Garrett et al., 1995). The predominant transcript is $5.4-\mathrm{kb}$ in length, while less abundant transcripts of 10, 4.8, and 4.2-kb are also found (Garrett et al., 1995). In human kidney, the 5.4-kb transcript is similarly predominant with the less abundant $10-\mathrm{kb}$ transcript also present (Aida et al., 1995).

The human CASR gene has two promoters driving transcription of alternative $5^{\prime}$ UTR exons (1A and 1B) (Chikatsu et al., 2000). By northern blot analysis of human parathyroid adenomas and normal glands, the 5.4 and $10-\mathrm{kb}$ transcripts (see above) appeared to be exclusive to exon $1 \mathrm{~A}$ use, while the $4.2-\mathrm{kb}$ transcripts are derived from either $1 \mathrm{~A}$ or $1 \mathrm{~B}$ (Chikatsu et al., 2000). Real-time PCR (qPCR) analysis of human parathyroid cells revealed that exon $1 \mathrm{~B}$-transcripts were much more highly expressed than exon 1A-containing transcripts (Mizobuchi et al., 2009). Transcripts of the 5.4 and $4.2-\mathrm{kb}$ size derive from use of the two alternative polyadenylation sites in the $3^{\prime}$ UTR tract (Chikatsu et al., 2000).

An exon 3-deleted CASR transcript has been reported in thyroid TT cells (Freichel et al., 1996), in placental cytotrophoblast (Bradbury et al., 1998), and in parathyroid, thyroid, and kidney (D'Souza-Li et al., 2001). Fusion of exon 2 to exon 4 results in a truncated protein that is poorly expressed and not trafficked to the cell surface.

In human keratinocytes, an alternatively spliced transcript lacking exon 5 encodes a variant CaSR with a 77-amino acid inframe deletion in the exodomain (Oda et al., 1998). This variant exerts a dominant negative effect on the full-length protein making it less responsive to calcium. In addition, the relative amounts of full-length vs. alternatively spliced transcript decrease during keratinocyte differentiation (Oda et al., 1998).

Consideration of alternatively spliced forms are of importance in phenotype evaluation of Casr mice knocked out by deletion of exon 5 (Ho et al., 1995). In the growth plate (Rodriguez et al., 2005), skin (Oda et al., 2000) and kidney (Oda et al., 2000) of the knockout mice, the Casr message lacking exon 5 is upregulated and compensates for the absence of the full-length counterpart in bone and cartilage (Rodriguez et al., 2005). Studies of Casr knockouts in which both fulllength and exon 5 transcripts are deleted have suggested that the exon 5-deletion model might be hypomorphic with respect to CaSR actions in the skeleton (Chang et al., 2008).

\section{Transcriptional Control of the CASR Gene}

Regulated CASR gene expression is important in growth and development (Riccardi et al., 2013), and in normal adult physiology (Brown, 2013) and in disease pathogenesis (Hannan and Thakker, 2013). Some of the factors and mechanisms involved in transactivation of the CASR gene have been identified (Hendy et al., 2013).
Human CASR transcription is driven by either promoter P1, with a TATA box at nucleotide -26 and a CCAAT box at -110 relative to the start site, or P2 with an $\mathrm{Sp} 1 / 3$ site at the transcriptional start site (Figure 1). The rat and mouse Casr genes have a similar organization. Both promoters drive significant levels of basal activity, with promoter P2 being 2.5-fold more active than P1 in most cell types examined as assessed by transfected promoter-reporter analysis (Canaff and Hendy, 2002). Also nuclear run-on assays that directly measure transcripts suggest greater exon $1 \mathrm{~B}$ relative to exon $1 \mathrm{~A}$ transcripts in human thyroid C-cells and renal proximal tubular cells. The presence of multiple promoters provides the potential for tissue-specific and/or developmental/temporal-specific regulated expression from one promoter vs. responsiveness to hormonal or nutritional stimuli from the other. Evidence for this has yet to be fully realized for the CASR gene. In fact, from studies done so far the opposite seems to be the case in that both promoters respond to active vitamin $\mathrm{D}$, cytokines, and the parathyroid cell-specific regulator, GCM2 (see below). However, pathophysiological differences in usage of the CASR gene promoters have been suggested.

Chikatsu et al. (2000) showed the expression of exon $1 \mathrm{~A}$ transcripts driven by the upstream promoter (P1), was decreased in adenomas, whereas expression of exon $1 \mathrm{~B}$ transcripts driven by the (normally stronger) promoter P2 was unchanged. These results suggested that $\mathrm{P} 1$ activity was reduced in parathyroid adenomas and is qualitatively in agreement with several studies showing a decrease in CaSR mRNA and protein expression in parathyroid adenomas relative to normal glands (Kifor et al., 1996; Farnebo et al., 1997; Gogusev et al., 1997; Cetani et al., 2000; Corbetta et al., 2000). However, other mechanisms yet to be identified are likely to contribute to the greater relative decreases in mRNA and protein expression that are not accounted for quantitatively by the $\sim 50 \%$ decrease of the apparently weaker P1 promoter. In a study of colorectal tumors, Kállay et al. (2003) found exon 1A transcript expression to be greater in the adjacent "normal" mucosa of colon cancer patients than in the tumor itself, and a highly significant decrease of exon 1A expression was found during progression from well-differentiated to poorly differentiated cancers whereas exon $1 \mathrm{~B}$ transcript expression was not significantly altered. More recent studies have found hypermethylation of promoter $\mathrm{P} 2$ that drives the exon $1 \mathrm{~B}$ transcripts (Fetahu et al., 2014a) and therefore reduced exon 1B transcript levels would be predicted. Further studies will be needed to resolve this apparent discrepancy.

\section{Vitamin D}

Active vitamin D increases CaSR expression and this has been documented in several studies in rodents. Parathyroid CaSR mRNA was reduced by $40 \%$ in vitamin D-depleted relative to replete rats, and $1,25(\mathrm{OH})_{2} \mathrm{D}_{3}$ administration to vitamin $\mathrm{D}$ replete rats enhanced parathyroid and kidney CaSR mRNA levels further (Brown et al., 1996). In another study administration of $1,25(\mathrm{OH})_{2} \mathrm{D}_{3}$ to rats upregulated renal CaSR mRNA levels in a dose-and time-dependent manner (Yao et al., 2005). Kidney CaSR expression (microarray analysis) was downregulated in VDR null mice relative to their wildtype littermates (Li et al., 
2003) and likewise (ribonuclease protection assay) for Cyp27-/mice lacking the 25-hydroxyvitamin D-1 $\alpha$-hydroxylase enzyme (Canaff et al., 2009a). Injection of $1,25(\mathrm{OH})_{2} \mathrm{D}_{3}$ in either normal mice or the Cyp27b1-/- mice caused upregulation of CaSR expression in parathyroid/thyroid and kidney (Li et al., 2003; Canaff et al., 2009a). Nuclear run-on assays that measure RNA transcripts showed that upregulation in thyroid and kidney cells occurred via gene transcription (Canaff and Hendy, 2002). Functional vitamin D response elements (VDREs) are present in both promoters, $\mathrm{P} 1$ and $\mathrm{P} 2$, of the human CASR gene (Canaff and Hendy, 2002) and are conserved in the rodent (Hendy et al., 2013). The VDREs of the CASR are typical in that they consist of two 6-bp half-sites separated by 3-bp that are bound by the vitamin $\mathrm{D}$ receptor (VDR)-retinoic acid X receptor (RXR) dimer. However, the VDREs are atypical in that the orientation of the half-sites is inverted to that which is normally found. VDREs of this type are found in the 25-hydroxyvitamin D-24-hydroxylase (CYP24A1) gene.

In the parathyroid gland, the $1,25(\mathrm{OH})_{2} \mathrm{D}$-upregulated CaSR makes the gland more responsive to extracellular $\mathrm{Ca}^{2+}$ and PTH secretion is reduced. The negative action of extracellular $\mathrm{Ca}^{2+}$ on PTH synthesis and secretion and parathyroid cell proliferation is reinforced by the active vitamin $\mathrm{D}$ metabolite. Impaired extracellular $\mathrm{Ca}^{2+}$-sensing that drives increased parathyroid cell proliferation may contribute to parathyroid neoplasia. Somatic CASR mutations are rare, but parathyroid glands of patients with primary or severe uremic secondary hyperparathyroidism often have reduced CaSR expression (Kifor et al., 1996; Cetani et al., 2000; Corbetta et al., 2000). Thus, reduction in components of the vitamin D system, active vitamin D ligand either circulating levels or produced by parathyroid intracrine action, and/or target VDR levels, that normally decrease PTH synthesis and secretion, could play an additional role by negating the normal inhibitory effects of extracellular $\mathrm{Ca}^{2+}$ on PTH via decreased CaSR expression.

The activated kidney CaSR that can act independently of PTH to directly determine the circulating $\mathrm{Ca}^{2+}$ concentration (Loupy et al., 2012) inhibits the paracellular uptake of cations in the cortical thick ascending limb of the distal nephron and promotes hypercalciuria. Autosomal dominant hypocalcemia type 1 (ADH1) patients are heterozygous for a gain-offunction mutant CASR. Treatment of ADH1 patients with active vitamin $\mathrm{D}$ upregulates the oversensitive renal CaSR stimulating $\mathrm{Ca}^{2+}$ excretion provoking nephrocalcinosis, nephrolithiasis, and potential renal damage (Pearce et al., 1996; Lienhardt et al., 2001). For such patients a better treatment option is vitamin $\mathrm{D}$ itself whereby the amount $1,25(\mathrm{OH})_{2} \mathrm{D}$ formed is limited by product inhibition of the 25-hydroxyvitamin D-1alphahydroxylase enzyme in the proximal tubule (Obermannova et al., 2016). In some genetic forms of hypercalciuria, altered regulation of CaSR expression by vitamin D metabolites may be a critical factor contributing to stone formation. In a genetic stoneforming rat model of hypercalciuric nephrolithiasis, nephron VDR levels are elevated, CaSR levels are increased and calcium reabsorption reduced (Yao et al., 2005; Bai and Favus, 2006).

Alterations of CaSR expression have been implicated not only in hyperparathyroidism but also other neoplasms. The CaSR is expressed in human colon epithelium and regulates cell proliferation and differentiation. Cells of the colon crypt acquire CaSR expression as they differentiate and migrate toward the apex of the crypt (Chakrabarty et al., 2005). CaSR expression is weak or absent in colon carcinomas and is inversely correlated with differentiation status. Extracellular $\mathrm{Ca}^{2+}$ and $1,25(\mathrm{OH})_{2} \mathrm{D}$ upregulate CASR transcription and cyclin-dependent kinase inhibitor expression in the colon and $\mathrm{Ca}^{2+}$ and $1,25(\mathrm{OH})_{2} \mathrm{D}$ may exert their chemopreventative actions with respect to colon cancer, in part, through the CaSR (Chakrabarty et al., 2005). Fetahu et al. (2014b) demonstrated the upregulation of CaSR expression by $1,25(\mathrm{OH})_{2} \mathrm{D}_{3}$ in colon cancer cells. This would be consistent with the active vitamin $\mathrm{D}$ metabolite exerting its antiproliferative, prodifferentiating effects in part by inducing expression of the tumor suppressor, CaSR.

Vascular calcification occurs during aging and pathologically in atherosclerosis and chronic kidney disease. There is an inverse relationship between vascular calcification and expression of the CaSR (Alam et al., 2009) and maintenance of its expression can protect against calcification (Molostvov et al., 2015). Treatment of vascular smooth muscle cells with active vitamin D increases CaSR mRNA and protein levels (Mary et al., 2015). This would be consistent with $1,25(\mathrm{OH})_{2} \mathrm{D}$ transactivation of the CASR gene via its VDREs (Canaff and Hendy, 2002). Treatment with cinacalcet that enhances sensitivity of the CaSR to $\mathrm{Ca}^{2+}$ promotes CaSR expression at the cell surface while overall CaSR expression is not altered (Hénaut et al., 2014). This would be consistent with ligand induced trafficking of the CaSR to the cell surface (Breitwieser, 2013) and $\mathrm{Ca}^{2+}$ within the normal range and higher having no marked effect on CASR gene expression (see below for further detail of potential regulation of CASR by extracellular $\mathrm{Ca}^{2+}$ ).

\section{Calcium}

In addition to $1,25(\mathrm{OH})_{2} \mathrm{D}$, a potential regulator of $C A S R$ gene expression is extracellular $\mathrm{Ca}^{2+}$ itself. Initial studies did not find an effect of extracellular $\mathrm{Ca}^{2+}$ on parathyroid gland or whole kidney CaSR mRNA in the rat in vivo (Rogers et al., 1995; Brown et al., 1996). A lack of effect on CASR expression by circulating $\mathrm{Ca}^{2+}$ is perhaps not unexpected in tissues such as parathyroid gland or kidney, where the CaSR plays a critical role in $\mathrm{Ca}^{2+}$ homeostasis as a calciostat to sense small changes in extracellular $\mathrm{Ca}^{2+}$ concentration. Even slight alterations in the extracellular $\mathrm{Ca}^{2+}$ set-point (the extracellular $\mathrm{Ca}^{2+}$ concentration at which PTH secretion from the parathyroid gland or calcium reabsorption across the kidney tubule is halfmaximal) brought about by changes in CaSR synthesis could disturb overall calcium homeostasis.

CaSR expression did not change in rats having altered circulating calcium levels as a result of infusion of $\mathrm{CaCl}_{2}$ or fed vitamin D-deficient diets supplemented with $\mathrm{Ca}^{2+}$ (Rogers et al., 1995; Brown et al., 1996). In these two studies the extracellular calcium levels ranged from 0.7 to $1.9 \mathrm{mM}$. However, potentially, lower or higher $\mathrm{Ca}^{+}$concentrations could regulate CaSR expression and perhaps in a tissue-specific manner.

CASR gene transcription was modulated by extracellular $\mathrm{Ca}^{+}$ in studies of transfected CASR promoter-reporter constructs in human kidney proximal tubule cells and mouse distal convoluted tubule cells (Canaff, 2004). In both cell types, when 
the concentration of $\mathrm{Ca}^{2+}$ in the media was varied from 1 to $5 \mathrm{mM}$, there was only a slight increase in P1 and P2 promoter activity. However, there was markedly reduced transcriptional activity of P1 (by 50\%) and P2 (by 30\%) in both proximal and distal convoluted tubule cell types when cultured in a very low $(0.25 \mathrm{mM}) \mathrm{Ca}^{2+}$ concentration. Therefore, from normal to high $\mathrm{Ca}^{2+}$ there was little regulation but from normal to low calcium there was significant regulation. The results from these in vitro experiments would be consistent with the lack of obvious effect of circulating $\mathrm{Ca}^{2+}$ in the in vivo studies referred to above (Rogers et al., 1995; Brown et al., 1996). In other cellsdifferentiated human colon carcinoma cells-upregulation of the CaSR occurred when the $\mathrm{Ca}^{2+}$ concentration of the culture medium was increased from very low to normal (Chakrabarty et al., 2005). Stimulatory effects of $\mathrm{Ca}^{2+}$ and $1,25(\mathrm{OH})_{2} \mathrm{D}$ were additive for promoter P2 but not for promoter P1 (Chakrabarty et al., 2005).

What would be the significance in the kidney of a reduced CaSR expression at low extracellular $\mathrm{Ca}^{2+}$ concentration? A decrease of CaSR expression in the proximal tubule would decrease the effect of calcium on the 25-hydroxyvitamin D1alpha-hydroxylase activity i.e., the negative impact of $\mathrm{Ca}^{2+}$ in decreasing enzyme activity would be minimized. In the ascending limb and distal convoluted tubule, the combination of a reduced CaSR expression and a low extracellular $\mathrm{Ca}^{2+}$ would favor maximal $\mathrm{Ca}^{2+}$ reabsorption from the tubule lumen and allow PTH to stimulate $\mathrm{Ca}^{2+}$ reabsorption without being antagonized by the CaSR.

The precise pathways by which extracellular $\mathrm{Ca}^{2+}$ might transactivate the CASR gene are not known. If the extracellular $\mathrm{Ca}^{2+}$ effect is mediated via the CaSR then a transcription factor activated by mitogen activated protein kinase (MAPK) (e.g., Elk1) could be involved. In addition, the involvement of transcription factors in the reduced expression of the CaSR in neoplasia of parathyroid and colon, for example, are not known. In an in vivo murine model of primary hyperparathyroidism in which cyclin D1 overexpression is targeted to the parathyroid, expression of the CaSR in the gland is markedly reduced and correlates with the severity of the hyperparathyroidism (Kawata et al., 2005). Treatment of the mice with the allosteric CaSR activator cinacalcet to mimic high levels of extracellular $\mathrm{Ca}^{2+}$ suppressed serum PTH and $\mathrm{Ca}^{2+}$ and parathyroid cell proliferation but had no effect on the levels of parathyroid CaSR mRNA (Imanishi et al., 2011). This reinforces the view that normal or higher extracellular $\mathrm{Ca}^{2+}$ concentrations do not significantly modulate parathyroid CaSR expression levels.

\section{Proinflammatory Cytokines}

Evidence has accumulated that the increased levels of circulating cytokines such as IL- $1 \beta$ and IL- 6 occurring in conditions of inflammation could provoke altered systemic $\mathrm{Ca}^{2+}$ homeostasis by modulating the setting of the calciostat-the expression of the CaSR. In critically ill patients such as those with sepsis and major burn injury hypocalcemia is common (Zaloga, 1992; Zivin et al., 2001; Steele et al., 2013) and in non-acutely ill patients undergoing surgery (Lepage et al., 1999). Serum IL-1 $\beta$ and IL6 levels increase within hours of severe burns and infection
(Kowal-Vern et al., 1994; Klein et al., 1995; Caldwell et al., 1997), and are inversely related to the falls in serum $\mathrm{Ca}^{2+}$ concentration (Lind et al., 2000) that may correlate with a poor prognosis (Guo et al., 1990; Nijsten et al., 1991; Schlüter et al., 1991; Ohzato et al., 1993; Yamada et al., 1996; Remick et al., 2002). Several factors such as decreased secretion of PTH and/or resistance to PTH action in kidney and bone may contribute to the hypocalcemia (Katz et al., 1992; Klein et al., 1997). In addition, the metabolism and action of vitamin D can be impaired. Calcitonin precursors are increased in the circulation of critically ill patients with sepsis (Lind et al., 2000; Müller et al., 2000; Becker et al., 2004, 2010). Certainly altered PTH secretion and action and vitamin $\mathrm{D}$ metabolism will be most important, whereas calcitonin plays a minor role in $\mathrm{Ca}^{2+}$ homeostatic control in human.

In patients with rheumatoid arthritis impaired secretion of PTH is inversely related to the inflammatory activity (Ekenstam et al., 1990). PTH secretion from bovine parathyroid cells was suppressed by IL-6 in vitro (Carlstedt et al., 1999) and the same effect was demonstrated for clinically relevant doses of IL-1 $\beta$ acting specifically via the IL-1 receptor in bovine parathyroid tissue slices in vitro with the added observation of upregulation of CaSR mRNA levels (Nielsen et al., 1997). Parathyroid CaSR mRNA levels were upregulated in an in vivo sheep model of burn injury in which increased circulating cytokine levels would occur (Murphey et al., 2000). Some proinflammatory cytokines can stimulate (rather than inhibit) the release of PTH. The IL$8 \mathrm{~B}$ receptor (CXCR2) was identified in the bovine parathyroid gland (Angeletti et al., 1998). Cultured bovine parathyroid cells responded to IL-8 with increases in PTH mRNA levels and PTH secretion, although any role of altered CaSR expression in these effects is as yet unknown.

Dysregulated PTH release and altered circulating $\mathrm{Ca}^{2+}$ levels occurs in septic horses (Toribio et al., 2001; Hurcombe et al., 2009). Equine parathyroid cells in culture responded to elevations in extracellular $\mathrm{Ca}^{2+}(0.8-2 \mathrm{mM})$ with decreased PTH mRNA while CaSR mRNA expression was unaltered consistent with other studies (see above) showing lack of an effect of extracellular $\mathrm{Ca}^{2+}$ on CaSR expression within this concentration range. IL$1 \beta$ acting via the IL-1 receptor decreased both PTH secretion and increased CaSR mRNA expression (Toribio et al., 2003). In rats in vivo serum PTH and $1,25(\mathrm{OH})_{2} \mathrm{D}$ decreased significantly $12 \mathrm{~h}$ after intraperitoneal (ip) injection of IL-1 $\beta$, followed by significantly decreased levels of serum $\mathrm{Ca}^{2+}$ at $15 \mathrm{~h}$ (Canaff and Hendy, 2005). In the same model, decreases in serum PTH and $1,25(\mathrm{OH})_{2} \mathrm{D}_{3}$ and calcium occurred after ip injection of IL-6 (Canaff et al., 2008b).

The CaSR in part mediates the antiproliferative and prodifferentiation actions of $\mathrm{Ca}^{2+}$ in colonocytes and can be considered as a tumor suppressor in the colon. Fetahu et al. (2014b) showed that in two differentiated colonocyte cell lines CaSR mRNA and protein levels increased in response to the cytokines, TNF $\alpha$, IL-1 $\beta$, and IL-6. The robust increase of CaSR expression could represent a defense against inflammation similar to what had been shown in murine macrophages, in which lipopolysaccharide-induced $\mathrm{TNF} \alpha$ release upregulated CaSR leading to negative feedback inhibition of synthesis of the cytokine (Kelly et al., 2011). 
Proinflammatory cytokines, like IL- $1 \beta$ and TNF- $\alpha$, work through NF-кB (nuclear factor kappa-light-chain-enhancer of activated B cells). NF- $\kappa \mathrm{B}$ exists in the cytoplasm of cells in an inactive form bound to an inhibitor, IКB. Upon receipt of a signal generated by activation of cytokine receptors, IкB is phosphorylated, and NF- $\kappa \mathrm{B}$ is released from IкB and translocates to the nucleus to upregulate specific gene transcription via specific $\kappa B$ response elements. NF- $\kappa B$ is responsible for the expression of many immune and inflammatory response (and other) proteins (Ghosh et al., 1998; Baldwin, 2001).

In the rat in vivo IL-1 $\beta$ upregulates parathyroid, thyroid, and kidney CASR mRNA and protein levels and stimulates endogenous CASR gene transcription in human thyroid and kidney cell lines (Canaff and Hendy, 2005). In addition, we showed that IL-1 $\beta$ and TNF- $\alpha$ upregulate CASR gene transcription via NF- $\kappa \mathrm{B}$ with functional $\kappa \mathrm{B}$ response elements being present in both promoters of the CASR gene (Canaff and Hendy, 2005).

At the cell surface, IL-6 binds the IL-6 receptor (IL-6R) consisting of an IL- 6 binding $\alpha$ chain (gp80) and the gp130 signal transducer that is shared among the IL-6-related cytokine subfamily members. IL- 6 binding to its receptor activates Janus kinase (JAK) family members that phosphorylate and activate signal transducers and activators of transcription (STAT) family members. The STATS dimerize, translocate to the nucleus and bind specific gene STAT-response elements activating transcription (Horvath, 2000; Levy and Darnell, 2002). STAT-1 and STAT-3 are responsible for IL-6 signaling. The JAKS may also couple to the MAPK pathway to modify the activity of transcription factors including STATs and others (Heinrich et al., 2003).

Intraperitoneal injection of IL-6 to rats in vivo caused decreases in serum PTH, $1,25(\mathrm{OH})_{2} \mathrm{D}$, and $\mathrm{Ca}^{2+}$ that were maintained over $24 \mathrm{~h}$ (Canaff et al., 2008b). Parathyroid, thyroid and kidney CaSR mRNA and protein levels were upregulated. IL-6 increased CASR gene transcription in human thyroid Ccell and kidney proximal tubule cells in vitro. CASR gene P1 and $\mathrm{P} 2$ promoter-driven transcripts were upregulated. Activation of the MAPK pathway contributed modestly to basal activity of both $\mathrm{P} 1$ and $\mathrm{P} 2$ promoters, but it was not involved in a major way in the IL- 6 induction of either of them (Canaff et al., 2008b). For promoter P1 a STAT1/3 element downstream of the transcriptional start site accounted for the IL-6 induction. For promoter P2 that has no STAT elements, IL- 6 rapidly promotes a complex containing both Sp1/3 and STAT1/3 on GC-rich elements that are clustered at the transcription start site.

The IL- 6 administration to rats resulted in a more rapid decrease in serum PTH, $1,25(\mathrm{OH})_{2} \mathrm{D}$ and $\mathrm{Ca}^{2+}$ levels than that occurring after IL-1 $\beta$ administration (Canaff and Hendy, 2005; Canaff et al., 2008b). The quicker response to IL-6 may relate to this cytokine's ability to induce rapid changes in mRNA translation and protein synthesis via the eukaryotic initiation factor-4F, as has been shown in sensory neurons, for example (Melemedjian et al., 2010). While IL-6 clearly regulates CASR gene transcription, uncovering any contribution of the cytokine at the post-transcriptional level with respect to the resetting of the calciostat will require further study.

\section{Other Considerations}

At sites of injury or infection the inflammatory response increases circulating proinflammatory cytokines leading to increased bone resorption. This occurs by enhanced osteocytic and osteoblastic production of receptor of activated NF- $\kappa$ B ligand (RANKL) resulting in increased osteoclastic bone resorption that releases $\mathrm{Ca}^{2+}$ from the bone (see Klein et al., 2016). One purpose of the increased extracellular $\mathrm{Ca}^{2+}$ concentration likely relates to its action as a chemokine on the one hand to recruit macrophages to sites of cell death and on the other to play a role in amplifying the inflammatory response via stimulating the assembly of a cytoplasmic multiprotein complex inflammasome that mediates proinflammatory cytokine maturation by activation of caspase-1 (see Hendy and Canaff, 2016 for further details).

Therefore, the CaSR in parathyroid gland and kidney executes its role in $\mathrm{Ca}^{2+}$ homeostasis but it is also expressed in monocytes and macrophages. This allows the CaSR to play critical roles in promoting and mediating the inflammatory response to tissue injury as well as minimizing or limiting these effects via its role in systemic $\mathrm{Ca}^{2+}$ homeostasis. Whether there is a place for the use of CaSR allosteric modulators in relevant clinical areas, for example, in reducing the degree of hypocalcemia in critically ill patients, remains to be explored. While extracellular $\mathrm{Ca}^{2+}$ is an activator of the NOD-like receptor family, pyrin domain-containing protein-3 (NLRP3) inflammasome, influenza virus infection also activates this particular inflammasome with resultant production of IL-1 $\beta$ (Allen et al., 2009; Owen and Gale, 2009; Thomas et al., 2009). This may be relevant to the observation that ADH1 patients with gain-of-function CASR mutations often become symptomatic (e.g., with seizures) during periods of intercurrent illness (Hendy et al., 2009). Enhanced expression of the activated CaSR by the increased circulating IL- $1 \beta$ cytokine would result in extracellular $\mathrm{Ca}^{2+}$ levels to drop further to symptomatic levels.

An additional pathological role for $\mathrm{Ca}^{2+}, \mathrm{CaSR}$, proinflammatory cytokines, and obesity has been suggested (Villarroel et al., 2014). It is proposed that $\mathrm{Ca}^{2+}$ activation of the CaSR in white adipose tissue preadipocytes increases proinflammatory cytokine production, proliferation and differentiation but decreased liped accumulation and adipose tissue dysfunction (Cifuentes et al., 2012). The obesity associated cytokines like TNF- $\alpha$ and IL- $1 \beta$ increase adipocyte CaSR expression (Cifuentes et al., 2010) by releasing $\mathrm{NF \kappa B}$ to translocate to the nucleus and activate the CASR gene at $\kappa \mathrm{B}$ response elements in its promoters (Canaff and Hendy, 2005). This represents a positive feed forward loop.

\section{Glial Cells Missing-2}

In Drosophila the transcription factor glial cells missing (GCM) acts as a developmental binary switch between glia and neurones. In mammals, there are two orthologs GCM1/GCMA and $G C M 2 / G C M B$ critical for parathyroid and placental development, respectively (Kim et al., 1998; Kammerer et al., 1999; Kanemura et al., 1999). The five exons of the GCM2 gene (OMIM\# 603716) on chromosome 6p24.2 encode a protein of 506 amino acids. GCM2 is expressed in the PTH-secreting cells of the parathyroid glands and is critical for their development 
in terrestrial vertebrates, and continues to be expressed in the adult (Günther et al., 2000; Maret et al., 2004; Okabe and Graham, 2004; Liu et al., 2007). From $\mathrm{NH}_{2}$ to $\mathrm{COOH}$ termini of the GCM2 protein there is a DNA-binding domain, transactivation domain 1 , an inhibitory domain, and transactivation domain 2 .

Homozygous or heterozygous inactivating mutations occur in familial isolated hypoparathyroidism (FIH) inherited in an autosomal recessive or dominant manner, respectively (Hendy and Cole, 2015). Autosomal recessive mutations include missense, stop, frameshift, and gene deletion, (e.g., Ding et al., 2001; Baumber et al., 2005; Thomée et al., 2005; Bowl et al., 2010; Tomar et al., 2010; Doyle et al., 2012). Autosomal dominant mutations include missense and single-nucleotide deletion (e.g., Mannstadt et al., 2008; Canaff et al., 2009b; Mirczuk et al., 2010; Yi et al., 2012). In vitro functional studies of some of these mutants have demonstrated loss of GCM response element binding and/transcriptional activity in the case of recessive mutations, as well as the ability of dominant mutants to inhibit activity of wild-type GCM2 when the two are transfected together into cells (Mannstadt et al., 2008; Canaff et al., 2009b; Mirczuk et al., 2010).

Genetic defects affecting GCM2 are rare in FIH: a study of 20 unrelated FIH cases (10 familial and 10 sporadic) found several polymorphic variants, but did not find GCM2 mutations that segregated with the disease and/or led to loss of function (Maret et al., 2008).

The CaSR is an early parathyroid differentiation marker (Liu et al., 2007). Absence or reduction of parathyroid GCM2, as in mice null for Gcm2 (Günther et al., 2000) or in cultured human parathyroid cells treated with GCM2 siRNA (Mizobuchi et al., 2009), correlates with lack or decreased expression of the CaSR. GCM2 transactivates the CASR gene via GCM response elements in promoters P1 and P2 (Canaff et al., 2008a, 2009b). Thus, GCM2 and CaSR are mechanistically linked with respect to the development of the evolutionarily related parathyroid glands (in terrestrial vertebrates) and gills (in fish) (Okabe and Graham, 2004).

v-maf musculo-aponeurotic fibrosarcoma oncogene homolog $\mathrm{B}(\mathrm{MafB})$, a transcriptional activator, is present in developing and mature parathyroid glands (Kamitani-Kawamoto et al., 2011). $\mathrm{MafB}$ acts downstream of GCM2 and ensures that the developing parathyroid glands properly localize between the thyroid and the thymus (Kamitani-Kawamoto et al., 2011). GCM2 associates with MafB to synergistically activate $P T H$ gene expression (Kawahara et al., 2010; Kamitani-Kawamoto et al., 2011).

Haploinsufficiency of the dual zinc-finger transcription factor, GATA3, results in the congenital hypoparathyroidism-deafnessrenal dysplasia (HDR) syndrome (Ali et al., 2007). Gata3 knockout mouse embryos lack Gcm2 expression and have gross defects in the third and fourth pharyngeal pouches including absent parathyroid-thymus primordia (Grigorieva et al., 2010). GATA3 transactivates the GCM2 gene by binding specifically to a double-GATA-motif within the GCM2 promoter. In addition, GATA3 cooperates with GCM2 and MafB to activate PTH gene expression by interacting with the ubiquitous specificity protein1 (SP1) transcription factor (Han et al., 2015). Thus, GATA3, GCM2 and MafB are part of a critical transcriptional cascade in the parathyroid morphogenesis and CaSR and PTH expression pathway (Grigorieva and Thakker, 2011; Han et al., 2015).

The persistance of GCM2 expression in the adult parathyroid raises the question of whether its overactivity or reduced expression could play a role in the development of parathyroid hyperfunction or tumorigenesis. In support of the first notion, increased expression of GCM2 has been noted in some adenomas of primary parathyroid patients (Kebebew et al., 2004). Furthermore, the allele frequency of a common Y282D polymorphism is significantly higher in Italian cohorts of primary hyperparathyroid patients than in normal individuals and the 282D variant exhibits higher activity on a GCM element promoter than Y282 (D'Agruma et al., 2014). In support of the second supposition, reduced levels of GCM2 mRNA have been reported in adenomatous tissue from some patients with primary hyperparathyroidism (Correa et al., 2002). This may contribute to the reduced CaSR expression commonly found in these tumors that might itself contribute to dysregulated control of parathyroid cell proliferation.

\section{CASR Expression and Kidney Stones}

Evidence has been provided that CaSR polymorphisms such as R990G can increase the susceptibility to hypercalciuria and urolithiasis (Liu et al., 2015). But single nucleotide polymorphisms (SNPs) within the regulatory regions of the CASR gene have also been associated with kidney stone risk, for example, in primary hyperparathyroidism (Vezzoli et al., 2011). A comparison of idiopathic calcium stone formers and healthy controls revealed one SNP (rs6776158 [A>G]) located in the CASR P1 promoter that was associated with nephrolithiasis (Vezzoli et al., 2013). $\mathrm{Sr}^{2+}$ handling has been proposed to be a mirror of $\mathrm{Ca}^{2+}$ metabolism and reduced $\mathrm{Sr}^{2+}$ excretion after an oral load was observed in GG homozygous stone formers. Activity of the G allele CASR P1 promoter-luciferase reporter was lower (than the A allele promoter) in cell transfection studies and CaSR mRNA levels were lower in kidney medulla samples in GG homozygous individuals than A allele carriers (Vezzoli et al., 2013). Therefore, the minor allele at rs6776158 may predispose to calcium stones by decreasing transcriptional activity of the CASR P1 promoter and CaSR expression in kidney tubules. Claudin-14 is a member of a superfamily of proteins that regulate paracellular transport of ions and small solutes at epithelial tight junctions. A mechanistic link between CASR gene activity was suggested by the finding that claudin-14 mRNA levels were lower in the CASR rs6776158 GG homozygous subjects Therefore, in these cases the predisposition to calcium nephrolithiasis is by a mechanism independent of hypercalciuria (Vezzoli et al., 2013). This hypothesis received further support by a comparison of another CASR gene regulatory SNP and R990G with respect to stone risk in primary hyperparathyroidism (Vezzoli et al., 2015).

In a genome-wide association study (GWAS) of Icelandic kidney stone cases a suggestive association of (rs7627468 [A]) in a CASR intron1 regulatory region was found in a large population set (Oddsson et al., 2015). A strong association was found for a polymorphism (rs199565725 [delAC]) in intron 1 of the CLDN14 gene encoding claudin-14 that might mediate a decrease in CLDN14 gene function. These data reinforced that of the same 
group in an earlier study (Thorleifsson et al., 2009). The authors observed uncorrelated genome-wide significant association of variants at the CASR locus that also influence biochemical traits, serum total and ionized calcium, for example, but do not associate with the kidney stone disease. This implies that the risk is not mediated solely through the serum level of calcium or other biochemical trait (Oddsson et al., 2015), and provides further indirect support for the CASR directed Claudin-14 mechanism (Gong et al., 2012; Gong and Hou, 2014; Toka et al., 2015; Riccardi and Valenti, 2016).

\section{CASR and Epigenetic Modification}

Altered CaSR expression occurs in benign and malignant tumors suggesting it as either a tumor suppressor or oncogene. The epigenetic inactivation of the CASR may underlie the reduced CaSR expression in some cancers. The CASR P2 promoter that is GC-rich, is methylated to a greater extent in colorectal tumors relative to adjacent mucosa and this correlates with the reduced CaSR levels in the tumors (Hizaki et al., 2011; Fetahu et al., 2014a). Use of histone deacetylase inhibitors in colon cancer cell lines most of which poorly express CaSR has implicated the involvement of $\mathrm{H} 3 \mathrm{~K} 9$ deacetylation in the silencing of CASR in colorectal cancer (Hizaki et al., 2011; Fetahu et al., 2014a). Similar findings with respect to methylation of the CASR P2 promoter were reported for unfavorable neuroblastomas in which CaSR is barely detectable (Casalà et al., 2013). In addition, monosomy of chromosome 3 where CASR resides was found in the vast majority of primary neuroblastic tumors of all types (Casalà et al., 2013). Hence the CASR is silenced by both genetic and epigenetic means in these tumors. However, no evidence has been found of loss of CASR alleles (Farnebo et al., 1997) or CASR gene methylation being responsible for the reduced CaSR levels in primary and secondary hyperparathyroidism (HofmanBang et al., 2012; Sulaiman et al., 2013; Varshney et al., 2013). Moreover, the molecular mechanisms underlying the enhanced expression of CaSR in breast and prostate tumors that implicates an oncogenic role for CaSR in these tissues have yet to be deciphered (Tennakoon et al., 2016).

\section{CaSR And MicroRNAs}

MicroRNAs (miRNAs) are short non-coding RNAs that function in RNA silencing and post-transcriptional regulation of gene expression. A further cause of silencing of the CaSR in colorectal tumors has been proposed to be increased expression of miR$135 \mathrm{~b}$ and miR-146b that are considered to be oncogenic (Fetahu et al., 2016). In colon cancer cell lines other miRNAs, miR21, miR-145, and miR-135a, are inversely correlated with CaSR expression (Singh and Chakrabarty, 2013; Singh et al., 2013). Altered expression of miRNAs may well have an important role

\section{REFERENCES}

Aida, K., Koishi, S., Tawata, M., and Onaya, T. (1995). Molecular cloning of a putative $\mathrm{Ca}^{2+}$-sensing receptor cDNA from human kidney. Biochem. Biophys. Res. Commun. 214, 524-529. doi: 10.1006/bbrc.1995.2318

Alam, M. U., Kirton, J. P., Wilkinson, F. L., Towers, E., Sinha, S., Rouhi, M., et al. (2009). Calcification is associated with loss of functional calcium-sensing in development of parathyroid tumors and miRNAs have been implicated in parathyroid function. Dicer-dependent maturation of parathyroid miRNAs is responsible for the dysregulated control of PTH secretion in a uremic mouse model of secondary hyperparathyroidism (Shilo et al., 2015). However, specific miRNAs that directly affect parathyroid CaSR expression have yet to be identified.

\section{PERSPECTIVES AND CONCLUSIONS}

The CaSR is expressed in the central nervous system and the roles it may play in the brain are being explored (Ruat and Traiffort, 2013). It will be important in future to understand the precise mechanisms underlying the postnatal upregulation of the brain CaSR during development and whether altered regulation of the CaSR plays a role in some cases of epilepsy. Within neurons the CaSR may play a role in susceptibility to Alzheimer's Disease (AD) and its progression (Chiarini et al., 2016). CASR expression may be altered in $\mathrm{AD}$ as it is regulated by the same transcription factors (e.g., SP1/3, AP1, STAT1/3, NF-кB, TFIID) already known to modulate other AD-regulated genes (Chiarini et al., 2016). However, this has yet to be directly evaluated.

The blood-brain barrier defends extracellular $\mathrm{Ca}^{2+}$ in the brain from changes in serum $\mathrm{Ca}^{2+}$ and at rest brain extracellular $\mathrm{Ca}^{2+}$ is maintained at $1.1 \mathrm{mM}$. During neuronal activity extracellular $\mathrm{Ca}^{2+}$ can fall sharply as $\mathrm{Ca}^{2+}$ moves to intracellular compartments. Following action potentials, $\mathrm{Ca}^{2+}$ can fall as low as $0.3 \mathrm{mM}$ in the synaptic cleft (Jones and Smith, 2016). Any potential changes on CASR gene expression and their consequences have yet to be examined.

Further insights to those described in the present review, can be anticipated with respect to identification of additional transcriptional factors and their cis-elements in the CASR gene promoters, epigenetic changes involving direct methylation of the CASR DNA as well as histone modifications and chromatin remodeling. The direct effect of miRNAs on degradation of CaSR mRNA or inhibition of its translation will become clearer.

\section{AUTHOR CONTRIBUTIONS}

All authors listed, have made substantial, direct and intellectual contribution to the work, and approved it for publication.

\section{ACKNOWLEDGMENTS}

Our work on the Calcium-sensing Receptor has been funded by the Canadian Institutes of Health Research, the Réseau de recherché en santé buccodentaire et osseuse, and the Kidney Foundation of Canada.

receptor in vascular smooth muscle cells. Cardiovas. Res. 81, 260-268. doi: $10.1093 / \mathrm{cvr} / \mathrm{cvn} 279$

Ali, A., Christie, P. T., Grigorieva, I. V., Harding, B., Van Esch, H., Ahmed, S. F., et al. (2007). Functional characterization of GATA3 mutations causing the hypoparathyroidism-deafness-renal (HDR) dysplasia syndrome: insight into mechanisms of DNA binding by the GATA3 transcription factor. Hum. Mol. Genet. 16, 265-275. doi: 10.1093/hmg/ddl454 
Allen, I. C., Scull, M. A., Moore, C. B., Holl, E. K., McElvania-TeKippe, E., Taxman, D. J., et al. (2009). The NLRP3 inflammasome mediates in vivo innate immunity to influenza A virus through recognition of viral RNA. Immunity 30, 556-565. doi: 10.1016/j.immuni.2009.02.005

Angeletti, R. H., D’Amico, T., Ashok, S., and Russell, J. (1998). The chemokine interleukin-8 regulates parathyroid secretion. J. Bone Miner. Res. 13, 1232-1237. doi: 10.1359/jbmr.1998.13.8.1232

Bai, S., and Favus, M. J. (2006). Vitamin D and calcium receptors: links to hypercalciuria. Curr. Opin. Nephrol. Hypertens. 15, 381-385. doi: 10.1097/01.mnh.0000232878.50716.26

Baldwin, A. S. (2001). Series introduction: the transcription factor NF-кB and human disease. J. Clin. Invest. 107, 3-6. doi: 10.1172/JCI11891

Baumber, L., Tufarelli, C., Patel, S., King, P., Johnson, C. A., Maher, E. R., et al. (2005). Identification of a novel mutation disrupting the DNA binding activity of GCM2 in autosomal recessive familial isolated hypoparathyroidism. J. Med. Genet. 42, 443-448. doi: 10.1136/jmg.2004.026898

Becker, K. L., Snider, R., and Nylen, E. S. (2010). Procalcitonin in sepsis and systemic inflammation: a harmful biomarker and a therapeutic target. $\mathrm{Br}$. J. Pharmacol. 159, 253-264. doi: 10.1111/j.1476-5381.2009.00433.x

Becker, K., Nylen, E., White, J., Muller, B., and Snider, R. Jr. (2004). Procalcitonin and the calcitonin gene family of peptides in inflammation, infection, and sepsis: a journey from calcitonin back to its precursors. J. Clin. Endocrinol. Metab. 89, 1512-1525. doi: 10.1210/jc.2002-021444

Bowl, M. R., Mirczuk, S. M., Grigorieva, I. V., Piret, S. E., Cranston, T., Southam, L., et al. (2010). Identification and characterization of novel parathyroid-specific transcription factor Glial Cells Missing Homolog B (GCMB) mutations in eight families with autosomal recessive hypoparathyroidism. Hum. Mol. Genet. 19, 2028-2038. doi: 10.1093/hmg/ddq084

Bradbury, R. A., Sunn, K. L., Crossley, M., Bai, M., Brown, E. M., Delbridge, L., et al. (1998). Expression of the parathyroid $\mathrm{Ca}(2+)$-sensing receptor in cytotrophoblasts from human term placenta. J. Endocrinol. 156, 425-430. doi: 10.1677/joe.0.1560425

Breitwieser, G. E. (2013). The calcium sensing receptor life cycle: trafficking, cell surface expression, and degradation. Best Pract. Res. Clin. Endocrinol. Metab. 27, 303-313. doi: 10.1016/j.beem.2013.03.003

Brennan, S. C., Thiem, U., Roth, S., Aggarwal, A., Fetahu, I., Tennakoon, S., et al. (2013). Calcium sensing receptor signalling in physiology and cancer. Biochim. Biophys. Acta 1833, 1732-1744. doi: 10.1016/j.bbamcr.2012.12.011

Brown, A., Zhong, M., Finch, J., Ritter, C., McCracken, R., Morrissey, J., et al. (1996). Rat calcium-sensing receptor is regulated by vitamin D but not by calcium. Am. J. Physiol. 270, F454-F460.

Brown, E. M. (2013). Role of the calcium-sensing receptor in extracellular calcium homeostasis. Best Pract. Res. Clin. Endocrinol. Metab. 27, 333-343. doi: 10.1016/j.beem.2013.02.006

Brown, E. M., Gamba, G., Riccardi, D., Lombardi, M., Butters, R., Kifor, O., et al. (1993). Cloning and characterization of an extracellular $\mathrm{Ca}^{2+}$-sensing receptor from bovine parathyroid. Nature 366, 575-580.

Caldwell, F. T. Jr., Graves, D. B., and Wallace, B. H. (1997). Pathogenesis of fever in a rat burn model: the role of cytokines and lipopolysaccharide. J. Burn Care Res. 18, 525-530. doi: 10.1097/00004630-199711000-00010

Canaff, L. (2004). Extracellular Calcium-Sensing Receptor: Studies of Gene Expression and Regulation. Doctoral dissertation, McGill University.

Canaff, L., and Hendy, G. N. (2002). Human calcium-sensing receptor gene. Vitamin D response elements in promoters $\mathrm{P} 1$ and $\mathrm{P} 2$ confer transcriptional responsiveness to 1, 25-dihydroxyvitamin D. J. Biol. Chem. 277, 30337-30350. doi: 10.1074/jbc.M201804200

Canaff, L., and Hendy, G. N. (2005). Calcium-sensing receptor gene transcription Is up-regulated by the proinflammatory cytokine, interleukin-1 $\beta$ : role of the NF- $\kappa \mathrm{B}$ pathway and $\kappa \mathrm{B}$ elements. J. Biol. Chem. 280, 14177-14188. doi: 10.1074/jbc.M4085 87200

Canaff, L., Petit, J.-L., Kisiel, M., Watson, P. H., Gascon-Barré, M., and Hendy, G. N. (2001). Extracellular calcium-sensing receptor is expressed in rat hepatocytes coupling to intracellular calcium mobilization and stimulation of bile flow. J. Biol. Chem. 276, 4070-4079. doi: 10.1074/jbc.M009317200

Canaff, L., Togola, D., Goltzman, D., and Hendy, G. N. (2009a). "Regulation of calcium-sensing receptor gene expression by 1,25-dihydroxyvitamin D in vivo: studies in mice lacking the 25-hydroxyvitamin D-1alpha-hydroxylase or vitamin D receptor genes," in ASBMR 31st Annual Meeting (Denver, CO).
Canaff, L., Zhou, X., Cole, D. E. C., and Hendy, G. N. (2008a). Glial cells missing-2 (GCM-2), the regulator of parathyroid cell fate, transactivates the calciumsensing receptor gene (CASR): identification of GCM-response elements in CASR promoters P1 and P2 [Abstract M187. P.S429]. J. Bone Miner. Res. 23 S1.

Canaff, L., Zhou, X., and Hendy, G. N. (2008b). The proinflammatory cytokine, interleukin-6, up-regulates calcium-sensing receptor gene transcription via Stat1/3 and Sp1/3. J. Biol. Chem. 283, 13586-13600. doi: 10.1074/jbc.M708087200

Canaff, L., Zhou, X., Mosesova, I., Cole, D. E., and Hendy, G. N. (2009b). Glial Cells Missing-2 (GCM2) transactivates the calcium-sensing receptor gene: effect of a dominant-negative GCM2 mutant associated with autosomal dominant hypoparathyroidism. Hum. Mutat. 30, 85-92. doi: 10.1002/humu.20827

Carlstedt, E., Ridefelt, P., Lind, L., and Rastad, J. (1999). Interleukin-6 induced suppression of bovine parathyroid hormone secretion. Biosci. Rep. 19, 35-42. doi: 10.1023/A:1020146023812

Casalà, C., Gil-Guiñón, E., Ordóñez, J. L., Miguel-Queralt, S., Rodríguez, E., Galván, P., et al. (2013). The calcium-sensing receptor is silenced by genetic and epigenetic mechanisms in unfavorable neuroblastomas and its reactivation induces ERK1/2-dependent apoptosis. Carcinogenesis 34, 268-276. doi: $10.1093 /$ carcin/bgs338

Cetani, F., Picone, A., Cerrai, P., Vignali, E., Borsari, S., Pardi, E., et al. (2000). Parathyroid expression of calcium-sensing receptor protein and in vivo parathyroid hormone- $\mathrm{Ca}^{2+}$ set-point in patients with primary hyperparathyroidism. J. Clin. Endocrinol. Metab. 85, 4789-4794. doi: $10.1210 /$ jc. 85.12 .4789

Chakrabarty, S., Wang, H., Canaff, L., Hendy, G. N., Appelman, H., and Varani, J. (2005). Calcium sensing receptor in human colon carcinoma: interaction with $\mathrm{Ca}^{2+}$ and 1, 25-dihydroxyvitamin D3. Cancer Res. 65, 493-498.

Chang, W., Tu, C., Chen, T.-H., Bikle, D., and Shoback, D. (2008). The extracellular calcium-sensing receptor (CaSR) is a critical modulator of skeletal development. Sci. Signal. 1:ra1. doi: 10.1126/scisignal.1159945

Chiarini, A., Armato, U., Liu, D., and Dal Prà, I. (2016). Calcium-sensing receptors of human neural cells play crucial roles in Alzheimer's Disease. Front. Physiol. 7:134. doi: 10.3389/fphys.2016.00134

Chikatsu, N., Fukumoto, S., Takeuchi, Y., Suzawa, M., Obara, T., Matsumoto, T., et al. (2000). Cloning and characterization of two promoters for the human calcium-sensing receptor (CaSR) and changes of CaSR expression in parathyroid adenomas. J. Biol. Chem. 275, 7553-7557. doi: 10.1074/jbc.275.11.7553

Cifuentes, M., Fuentes, C., Mattar, P., Tobar, N., Hugo, E., Ben-Jonathan, N., et al. (2010). Obesity-associated proinflammatory cytokines increase calcium sensing receptor (CaSR) protein expression in primary human adipocytes and LS14 human adipose cell line. Arch. Biochem. Biophys. 500, 151-156. doi: 10.1016/j.abb.2010.05.033

Cifuentes, M., Fuentes, C., Tobar, N., Acevedo, I., Villalobos, E., Hugo, E., et al. (2012). Calcium sensing receptor activation elevates proinflammatory factor expression in human adipose cells and adipose tissue. Mol. Cell. Endocrinol. 361, 24-30. doi: 10.1016/j.mce.2012.03.006

Corbetta, S., Mantovani, G., Lania, A., Borgato, S., Vicentini, L., Faglia, G., et al. (2000). Calcium-sensing receptor expression and signalling in human parathyroid adenomas and primary hyperplasia. Clin. Endocrinol. (Oxf). 52, 339-348. doi: 10.1046/j.1365-2265.2000.00933.x

Correa, P., Akerström, G., and Westin, G. (2002). Underexpression of Gcm2, a master regulatory gene of parathyroid gland development, in adenomas of primary hyperparathyroidism. Clin. Endocrinol. (Oxf). 57, 501-505. doi: 10.1046/j.1365-2265.2002.01627.x

D’Agruma, L., Coco, M., Guarnieri, V., Battista, C., Canaff, L., Salcuni, A. S., et al. (2014). Increased prevalence of the GCM2 polymorphism, Y282D, in primary hyperparathyroidism: analysis of three Italian cohorts. J. Clin. Endocrinol. Metab. 99, E2794-E2798. doi: 10.1210/jc.2014-2857

D'Souza-Li, L., Canaff, L., Janicic, N., Cole, D. E., and Hendy, G. N. (2001). An acceptor splice site mutation in the calcium-sensing receptor (CASR) gene in familial hypocalciuric hypercalcemia and neonatal severe hyperparathyroidism. Hum. Mutat. 18, 411-421. doi: 10.1002/humu.1212

Ding, C., Buckingham, B., and Levine, M. A. (2001). Familial isolated hypoparathyroidism caused by a mutation in the gene for the transcription factor GCMB. J. Clin. Invest. 108, 1215-1220. doi: 10.1172/JCI13180

Doyle, D., Kirwin, S. M., Sol-Church, K., and Levine, M. A. (2012). A novel mutation in the GCM2 gene causing severe congenital isolated 
hypoparathyroidism. J. Pediatr. Endocrinol. Metab. 25, 741-746. doi: 10.1515/jpem-2012-0080

Ekenstam, E. A., Benson, L., Hallgren, R., Wide, L., and Ljunghall, S. (1990). Impaired secretion of parathyroid hormone in patients with rheumatoid arthritis: relationship to inflammatory activity. Clin. Endocrinol. (Oxf). 32, 323-328. doi: 10.1111/j.1365-2265.1990.tb00873.x

Farnebo, F., Enberg, U., Grimelius, L., Bäckdahl, M., Schalling, M., Larsson, C., et al. (1997). Tumor-specific decreased expression of calcium sensing receptor messenger ribonucleic acid in sporadic primary hyperparathyroidism 1. J. Clin. Endocrinol. Metab. 82, 3481-3486. doi: 10.1210/jc.82.10.3481

Fetahu, I. S., Höbaus, J., Aggarwal, A., Hummel, D. M., Tennakoon, S., Mesteri, I., et al. (2014a). Calcium-sensing receptor silencing in colorectal cancer is associated with promoter hypermethylation and loss of acetylation on histone 3. Int. J. Cancer 135, 2014-2023. doi: 10.1002/ijc.28856

Fetahu, I. S., Hummel, D. M., Manhardt, T., Aggarwal, A., Baumgartner-Parzer, S., and Kállay, E. (2014b). Regulation of the calcium-sensing receptor expression by 1,25-dihydroxyvitamin $\mathrm{D} 3$, interleukin-6, and tumor necrosis factor alpha in colon cancer cells. J. Steroid Biochem. Mol. Biol. 144(Pt A), 228-2231. doi: 10.1016/j.jsbmb.2013.10.015

Fetahu, I. S., Tennakoon, S., Lines, K. E., Gröschel, C., Aggarwal, A., Mesteri, I., et al. (2016). miR-135b- and miR-146b-dependent silencing of calcium-sensing receptor expression in colorectal tumors. Int. J. Cancer 138, 137-145. doi: $10.1002 / \mathrm{ijc} .29681$

Freichel, M., Zink-Lorenz, A., Holloschi, A., Hafner, M., Flockerzi, V., and Raue, F. (1996). Expression of a calcium-sensing receptor in a human medullary thyroid carcinoma cell line and its contribution to calcitonin secretion. Endocrinology 137, 3842-3848. doi: 10.1210/endo.137.9.8756555

Garrett, J. E., Capuano, I. V., Hammerland, L. G., Hung, B. C., Brown, E. M., Hebert, S. C., et al. (1995). Molecular cloning and functional expression of human parathyroid calcium receptor cDNAs. J. Biol. Chem. 270, 12919-12925. doi: 10.1074/jbc.270.21.12919

Ghosh, S., May, M. J., and Kopp, E. B. (1998). NF-kappa B and Rel proteins: evolutionarily conserved mediators of immune responses. Annu. Rev. Immunol. 16, 225-260. doi: 10.1146/annurev.immunol.16.1.225

Gogusev, J., Duchambon, P., Hory, B., Giovannini, M., Goureau, Y., Sarfati, E., et al. (1997). Depressed expression of calcium receptor in parathyroid gland tissue of patients with hyperparathyroidism. Kidney Int. 51, 328-336. doi: 10.1038/ki.1997.41

Goltzman, D., and Hendy, G. N. (2015). The calcium-sensing receptor in bone mechanistic and therapeutic insights. Nat. Rev. Endocrinol. 11, 298-307. doi: $10.1038 /$ nrendo. 2015.30

Gong, Y., and Hou, J. (2014). Claudin-14 underlies $\mathrm{Ca}^{++}$-sensing receptormediated $\mathrm{Ca}^{++}$metabolism via NFAT-microRNA-based mechanisms. J. Am. Soc. Nephrol. 25, 745-760. doi: 10.1681/ASN.2013050553

Gong, Y., Renigunta, V., Himmerkus, N., Zhang, J., Renigunta, A., Bleich, M., et al. (2012). Claudin-14 regulates renal $\mathrm{Ca}^{++}$transport in response to CaSR signalling via a novel microRNA pathway. EMBO J. 31, 1999-2012. doi: 10.1038/emboj.2012.49

Grigorieva, I. V., Mirczuk, S., Gaynor, K. U., Nesbit, M. A., Grigorieva, E. F., Wei, Q., et al. (2010). Gata3-deficient mice develop parathyroid abnormalities due to dysregulation of the parathyroid-specific transcription factor Gcm2. J. Clin. Invest. 120, 2144-2155. doi: 10.1172/JCI42021

Grigorieva, I. V., and Thakker, R. V. (2011). Transcription factors in parathyroid development: lessons from hypoparathyroid disorders. Ann. N. Y. Acad. Sci. 1237, 24-38. doi: 10.1111/j.1749-6632.2011.06221.x

Günther, T., Chen, Z. F., Kim, J., Priemel, M., Rueger, J. M., Amling, M., et al. (2000). Genetic ablation of parathyroid glands reveals another source of parathyroid hormone. Nature 406, 199-203. doi: 10.1038/35018111

Guo, Y., Dickerson, C., Chrest, F. J., Adler, W. H., Munster, A. M., and Winchurch, R. A. (1990). Increased levels of circulating interleukin 6 in burn patients. Clin. Immunol. Immunopathol. 54, 361-371. doi: 10.1016/0090-1229(90)90050-Z

Hannan, F. M., and Thakker, R. V. (2013). Calcium-sensing receptor (CaSR) mutations and disorders of calcium, electrolyte and water metabolism. Best Pract. Res. Clin. Endocrinol. Metab. 27, 359-371. doi: 10.1016/j.beem.2013.04.007

Han, S.-I., Tsunekage, Y., and Kataoka, K. (2015). Gata3 cooperates with Gcm2 and MafB to activate parathyroid hormone gene expression by interacting with SP1. Mol. Cell. Endocrinol. 411, 113-120. doi: 10.1016/j.mce.2015.04.018
Heinrich, P. C., Behrmann, I., Haan, S., Hermanns, H. M., Müller-Newen, G., and Schaper, F. (2003). Principles of interleukin (IL)-6-type cytokine signalling and its regulation. Biochem. J. 374, 1-20. doi: 10.1042/bj20030407

Hénaut, L., Boudot, C., Massy, Z. A., Lopez-Fernandez, I., Dupont, S., Mary, A., et al. (2014). Calcimimetics increase CaSR expression and reduce mineralization in vascular smooth muscle cells: mechanisms of action. Cardiovasc. Res. 101, 256-265. doi: 10.1093/cvr/cvt249

Hendy, G. N., and Canaff, L. (2016). Calcium-sensing receptor, proinflammatory cytokines and calcium homeostasis. Semin. Cell. Dev. Biol. 49, 37-43. doi: 10.1016/j.semcdb.2015.11.006

Hendy, G. N., Canaff, L., and Cole, D. E. (2013). The CASR gene: alternative splicing and transcriptional control, and calcium-sensing receptor (CaSR) protein: structure and ligand binding sites. Best Pract. Res. Clin. Endocrinol. Metab. 27, 285-301. doi: 10.1016/j.beem.2013.02.009

Hendy, G. N., and Cole, D. E. C. (2015). "Familial isolated hypoparathyroidism," in Hypoparathyroidism, eds M. L. Brandi and E. M. Brown (Springer-Verlag Italia), 167-175.

Hendy, G. N., Guarnieri, V., and Canaff, L. (2009). Calcium-sensing receptor and associated diseases. Prog. Mol. Biol. Transl. Sci. 89, 31-95. doi: 10.1016/S18771173(09)89003-0

Hizaki, K., Yamamoto, H., Taniguchi, H., Adachi, Y., Nakazawa, M., Tanuma, T., et al. (2011). Epigenetic inactivation of calcium-sensing receptor in colorectal carcinogenesis. Mod. Pathol. 24, 876-884. doi: 10.1038/modpathol.2011.10

Ho, C., Conner, D. A., Pollak, M. R., Ladd, D. J., Kifor, O., Warren, H. B., et al. (1995). A mouse model of human familial hypocalciuric hypercalcemia and neonatal severe hyperparathyroidism. Nat. Genet. 11, 389-394. doi: $10.1038 / \mathrm{ng} 1295-389$

Hofman-Bang, J., Gravesen, E., Olgaard, K., and Lewin, E. (2012). Epigenetic methylation of parathyroid $\mathrm{CaR}$ and VDR promoters in experimental secondary hyperparathyroidism. Int. J. Nephrol. 2012:123576. doi: $10.1155 / 2012 / 123576$

Horvath, C. M. (2000). STAT proteins and transcriptional responses to extracellular signals. Trends Biochem. Sci. 25, 496-502. doi: 10.1016/S09680004(00)01624-8

Hurcombe, S. D., Toribio, R. E., Slovis, N. M., Saville, W. J., Mudge, M. C., Macgillivray, K., et al. (2009). Calcium regulating hormones and serum calcium and magnesium concentrations in septic and critically ill foals and their association with survival. J. Vet. Intern. Med. 23, 335-343. doi: 10.1111/j.19391676.2009.0275.x

Imanishi, Y., Kawata, T., Kenko, T., Wada, M., Nagano, N., Miki, T., et al. (2011). Cinacalcet HCl suppresses Cyclin D1 oncogene-derived parathyroid cell proliferation in a murine model for primary hyperparathyroidism. Calcif. Tissues Int. 89, 29-35. doi: 10.1007/s00223-011-9490-4

Janicic, N., Soliman, E., Pausova, Z., Seldin, M. F., Rivière, M., Szpirer, J., et al. (1995). Mapping of the calcium-sensing receptor gene (CASR) to human chromosome 3q13. 3-21 by fluorescence in situ hybridization, and localization to rat chromosome 11 and mouse chromosome 16. Mamm. Genome 6, 798-801.

Jones, B. L., and Smith, S. M. (2016). Calcium-sensing receptor: a key target for extracellular calcium signaling in neurons. Front. Physiol. 7:116. doi: 10.3389/fphys.2016.00116.

Kállay, E., Bonner, E., Wrba, F., Thakker, R. V., Peterlik, M., and Cross, H. S. (2003). Molecular and functional characterization of the extracellular calcium-sensing receptor in human colon cancer cells. Oncol. Res. Featuring Preclin. Clin. Cancer Ther. 13, 551-559.

Kamitani-Kawamoto, A., Hamada, M., Moriguchi, T., Miyai, M., Saji, F., Hatamura, I., et al. (2011). MafB interacts with $\mathrm{Gcm} 2$ and regulates parathyroid hormone expression and parathyroid development. J. Bone Miner. Res. 26, 2463-2472. doi: 10.1002/jbmr.458

Kammerer, M., Pirola, B., Giglio, S., and Giangrande, A. (1999). GCMB, a second human homolog of the fly glide/gcm gene. Cytogenet. Cell Genet. 84, 43-47.

Kanemura, Y., Hiraga, S., Arita, N., Ohnishi, T., Izumoto, S., Mori, K., et al. (1999). Isolation and expression analysis of a novel human homologue of the Drosophila glial cells missing ( $\mathrm{gcm}$ ) gene. FEBS Lett. 442, 151-156.

Katz, M. S., Gutierrez, G. E., Mundy, G. R., Caulfield, M. P., Hymer, T. K., and McKee, R. L. (1992). Tumor necrosis factor and interleukin 1 inhibit parathyroid hormone-responsive adenylate cyclase in clonal osteoblast-like cell by down-regulating parathyroid hormone receptors. J. Cell. Physiol. 153, 206-213. doi: 10.1002/jcp.1041530125 
Kawahara, M., Iwasaki, Y., Sakaguchi, K., Taguchi, T., Nishiyama, M., Nigawara, T., et al. (2010). Involvement of GCMB in the transcriptional regulation of the human parathyroid hormone gene in a parathyroid-derived cell line PT-r: effects of calcium and 1,25(OH)2D3. Bone 47, 534-541. doi: 10.1016/j.bone.2010.05.031

Kawata, T., Imanishi, Y., Kobayashi, K., Kenko, T., Wada, M., Ishimura, E., et al. (2005). Relationship between parathyroid calcium-sensing receptor expression and potency of the calcimimetic, cinacalcet, in suppressing parathyroid hormone secretion in an in vivo murine model of primary hyperparathyroidism. Eur. J. Endocrinol. 153, 587-594. doi: 10.1530/eje.1.02007

Kebebew, E., Peng, M., Wong, M. G., Ginzinger, D., Duh, Q.-Y., and Clark, O. H. (2004). GCMB gene, a master regulator of parathyroid gland development, expression, and regulation in hyperparathyroidism. Surgery 136, 1261-1266. doi: 10.1016/j.surg.2004.06.056

Kelly, J. C., Lungchukiet, P., and MacLeod, R. J. (2011). Extracellular calcium-sensing receptor inhibition of intestinal epithelial TNF signaling requires CaSR-mediated Wnt5a/Ror2 interaction. Front. Physiol. 2:17. doi: $10.3389 /$ fphys.2011.00017

Kifor, O., Moore, F. Jr., Wang, P., Goldstein, M., Vassilev, P., Kifor, I., et al. (1996). Reduced immunostaining for the extracellular $\mathrm{Ca}^{2+}$-sensing receptor in primary and uremic secondary hyperparathyroidism. J. Clin. Endocrinol. Metab. 81, 1598-1606.

Kim, J., Jones, B. W., Zock, C., Chen, Z., Wang, H., Goodman, C. S., et al. (1998). Isolation and characterization of mammalian homologs of the Drosophila gene glial cells missing. Proc. Natl. Acad. Sci. U.S.A. 95, 12364-12369.

Klein, G. L., Castro, S. M., and Garofalo, R. P. (2016). The calcium-sensing receptor as a mediator of inflammation. Semin. Cell. Dev. Biol. 49, 52-56. doi: 10.1016/j.semcdb.2015.08.006

Klein, G. L., Herndon, D. N., Goodman, W. G., Langman, C. B., Phillips, W. A., Dickson, I. R., et al. (1995). Histomorphometric and biochemical characterization of bone following acute severe burns in children. Bone 17, 455-460. doi: 10.1016/8756-3282(95)00279-1

Klein, G. L., Nicolai, M., Langman, C. B., Cuneo, B. F., Sailer, D. E., and Herndon, D. N. (1997). Dysregulation of calcium homeostasis after severe burn injury in children: possible role of magnesium depletion. J. Pediatr. 131, 246-251. doi: 10.1016/S0022-3476(97)70161-6

Kowal-Vern, A., Walenga, J. M., Hoppensteadt, D., Sharp-Pucci, M., and Gamelli, R. L. (1994). Interleukin-2 and interleukin-6 in relation to burn wound size in the acute phase of thermal injury. J. Am. Coll. Surg. 178, 357-362.

Lepage, R., Légaré, G., Racicot, C., Brossard, J.-H., Lapointe, R., Dagenais, M., et al. (1999). Hypocalcemia induced during major and minor abdominal surgery in humans. J. Clin. Endocrinol. Metab. 84, 2654-2658. doi: 10.1210/jcem.84.8.5889

Levy, D. E., and Darnell, J. (2002). Stats: transcriptional control and biological impact. Nat. Rev. Mol. Cell Biol. 3, 651-662. doi: 10.1038/nrm909

Lienhardt, A., Bai, M., Lagarde, J.-P., Rigaud, M., Zhang, Z., Jiang, Y., et al. (2001). Activating mutations of the calcium-sensing receptor: management of hypocalcemia. J. Clin. Endocrinol. Metab. 86, 5313-5323. doi: $10.1210 /$ jcem. 86.11 .8016

Lind, L., Carlstedt, F., Rastad, J., Stiernström, H., Stridsberg, M., Ljunggren, Ö., et al. (2000). Hypocalcemia and parathyroid hormone secretion in critically ill patients. Crit. Care Med. 28, 93-99. doi: 10.1097/00003246-200001000-00015

Liu, K., Wang, X., Ye, J., Qin, C., Shao, P., Zhang, W., et al. (2015). The G allele of CaSR R990G polymorphism increases susceptibility to urolithiasis and hypercalciuria: evidences from a comprehensive meta-analysis. Biomed. Res. Int. 2015:958207. doi: 10.1155/2015/958207

Liu, Z., Yu, S., and Manley, N. R., (2007). Gcm2 is required for the differentiation and survival of parathyroid precursor cells in the parathyroid/thymus primordia. Dev. Biol. 305, 333-346. doi: 10.1016/j.ydbio.2007.02.014

Li, X., Zheng, W., and Li, Y. C. (2003). Altered gene expression profile in the kidney of vitamin D receptor knockout mice. J. Cell. Biochem. 89, 709-719. doi: $10.1002 / j c b .10547$

Loretz, 2008\#\#\#Loretz, C. A. (2008). Extracellular calcium-sensing receptors in fishes. Comp. Biochem. Physiol. Part A: Mol. Integr. Physiol. 149, 225-245. doi: 10.1016/j.cbpa.2008.01.037

Loupy, A., Ramakrishnan, S. K., Wootla, B., Chambrey, R., de la Faille, R., Bourgeois, S., et al. (2012). PTH-independent regulation of blood calcium concentration by the calcium-sensing receptor. J. Clin. Invest. 122, 3355-3367. doi: 10.1172/JCI57407
Mannstadt, M., Bertrand, G., Muresan, M., Weryha, G., Leheup, B., Pulusani, S. R., et al. (2008). Dominant-negative GCMB mutations cause an autosomal dominant form of hypoparathyroidism. J. Clin. Endocrinol. Metab. 93, 3568-3576. doi: 10.1210/jc.2007-2167

Maret, A., Bourdeau, I., Ding, C., Kadkol, S. S., Westra, W. H., and Levine, M. A. (2004). Expression of GCMB by intrathymic parathyroid hormone-secreting adenomas indicates their parathyroid cell origin. J. Clin. Endocrinol. Metab. 89, 8-12. doi: 10.1210/jc.2003-030733

Maret, A., Ding, C., Kornfield, S. L., and Levine, M. A. (2008). Analysis of the GCM2 gene in isolated hypoparathyroidism: a molecular and biochemical study. J. Clin. Endocrinol. Metab. 93, 1426-1432. doi: 10.1210/jc.2007-1783

Mary, A., Hénaut, L., Boudot, C., Six, I., Brazier, M., Massy, Z. A., et al. (2015). Calcitriol prevents in vitro vascular smooth muscle cell mineralization by regulating calcium-sensing receptor expression. Endocrinology 156, 1965-1974. doi: 10.1210/en.2014-1744

Melemedjian, O. K., Asiedu, M. N., Tillu, D. V., Peebles, K. A., Yan, J., Ertz, N. et al. (2010). IL-6-and NGF-induced rapid control of protein synthesis and nociceptive plasticity via convergent signaling to the eIF $4 \mathrm{~F}$ complex. J. Neurosci. 30, 15113-15123. doi: 10.1523/JNEUROSCI.3947-10.2010

Mirczuk, S. M., Bowl, M. R., Nesbit, M. A., Cranston, T., Fratter, C., Allgrove, J., et al. (2010). A missense glial cells missing homolog B (GCMB) mutation, Asn502His, causes autosomal dominant hypoparathyroidism. J. Clin. Endocrinol. Metab. 95, 3512-3516. doi: 10.1210/jc.2009-2532

Mizobuchi, M., Ritter, C. S., Krits, I., Slatopolsky, E., Sicard, G., and Brown, A. J. (2009). Calcium-sensing receptor expression is regulated by glial cells missing-2 in human parathyroid cells. J. Bone Miner. Res. 24 1173-1179. doi: 10.1359/jbmr.090211

Molostvov, G., Hiemstra, T. F., Fletcher, S., Bland, R., and Zehnder, D. (2015). Arterial Expression of the calcium-sensing receptor is maintained by physiological pulsation and protects against calcification. PLOS ONE 10:e0138833. doi: 10.1371/journal.pone. 0138833

Müller, B., Becker, K., Kränzlin, M., Schachinger, H., Huber, P., Nylen, E., et al. (2000). Disordered calcium homeostasis of sepsis: association with calcitonin precursors. Eur. J. Clin. Invest. 30, 823-831. doi: 10.1046/j.13652362.2000.00714.x

Murphey, E., Chattopadhyay, N., Bai, M., Kifor, O., Harper, D., Traber, D. L., et al. (2000). Up-regulation of the parathyroid calcium-sensing receptor after burn injury in sheep: a potential contributory factor to postburn hypocalcemia. Crit. Care Med. 28, 3885-3890. doi: 10.1097/00003246-200012000-00024

Naito, T., Saito, Y., Yamamoto, J., Nozaki, Y., Tomura, K., Hazama, M., et al. (1998). Putative pheromone receptors related to the $\mathrm{Ca}^{2+}$-sensing receptor in Fugu. Proc. Natl. Acad. Sci. U.S.A. 95, 5178-5181. doi: 10.1073/pnas.95.9.5178

Nielsen, P., Rasmussen, A. K., Butters, R., Feldt-Rasmussen, U., Bendtzen, K., Diaz, R., et al. (1997). Inhibition of PTH secretion by Interleukin-1 $\beta$ in bovine parathyroid glands in vitro Is associated with an up-regulation of the CalciumSensing Receptor mRNA. Biochem. Biophys. Res. Commun. 238, 880-885. doi: 10.1006/bbrc.1997.7207

Nijsten, M. W., Hack, C. E., Helle, M., Ten Duis, H. J., Klasen, H. J., and Aarden, L. A. (1991). Interleukin- 6 and its relation to the humoral immune response and clinical parameters in burned patients. Surgery 109, 761-767.

Obermannova, B., Sumnik, A., Dusatkova, P., Cinek, O., Grant, M., Lebl, J., et al. (2016). Novel calcium-sensing receptor cytoplasmic tail deletion mutation causing autosomal dominant hypocalcemia: molecular and clinical study. Eur. J. Endocrinol. 174, K1-K11. doi: 10.1530/EJE-15-1216

Oda, Y., Tu, C.-L., Chang, W., Crumrine, D., Kömüves, L., Mauro, T., et al. (2000). The calcium sensing receptor and its alternatively spliced form in murine epidermal differentiation. J. Biol. Chem. 275, 1183-1190. doi: $10.1074 /$ jbc.275.2.1183

Oda, Y., Tu, C.-L., Pillai, S., and Bikle, D. D. (1998). The calcium sensing receptor and its alternatively spliced form in keratinocyte differentiation. J. Biol. Chem. 273, 23344-23352. doi: 10.1074/jbc.273.36.23344

Oddsson, A., Sulem, P., Helgason, H., Edvardsson, V. O., Thorleifsson, G., Sveinbjörnsson, G., et al. (2015). Common and rare variants associated with kidney stones and biochemical traits. Nat. Commun. 6:7975. doi: 10.1038/ncomms8975

Ohzato, H., Monden, M., Yoshizaki, K., Ogata, A., Nishimoto, N., Gotoh, M., et al. (1993). Systemic production of interleukin-6 following acute inflammation. Biochem. Biophys. Res. Commun. 197, 1556-1562. doi: 10.1006/bbrc.19 93.2655 
Okabe, M., and Graham, A. (2004). The origin of the parathyroid gland. Proc. Natl. Acad. Sci. U.S.A. 101, 17716-17719. doi: 10.1073/pnas.0406116101

Owen, D. M., and Gale, M. Jr. (2009). Fighting the flu with inflammasome signaling. Immunity 30, 476-478. doi: 10.1016/j.immuni.2009.03.011

Pearce, S. H., Williamson, C., Kifor, O., Bai, M., Coulthard, M. G., Davies, M., et al. (1996). A familial syndrome of hypocalcemia with hypercalciuria due to mutations in the calcium-sensing receptor. N. Eng. J. Med. 335, 1115-1122. doi: 10.1056/NEJM199610103351505

Pollak, M. R., Brown, E., Chou, Y., Hebert, S., Marx, S., and Steinman, B. (1993). Mutations in the human $\mathrm{Ca}^{2+}$ sensing receptor gene cause familial hypocalciuric hypercalcemia and neonatal severe hyperparathyroidism. Cell 75, 1297-1303. doi: 10.1016/0092-8674(93)90617-Y

Remick, D. G., Bolgos, G. R., Siddiqui, J., Shin, J., and Nemzek, J. A. (2002). Six at six: interleukin- 6 measured $6 \mathrm{~h}$ after the initiation of sepsis predicts mortality over 3 days. Shock 17, 463-467. doi: 10.1097/00024382-200206000-00004

Riccardi, D., Brennan, S. C., and Chang, W. (2013). The extracellular calciumsensing receptor, CaSR, in fetal development. Best Pract. Res. Clin. Endocrinol. Metab. 27, 443-453. doi: 10.1016/j.beem.2013.02.010

Riccardi, D., and Valenti, G. (2016). Localization and function of the renal calciumsensing receptor. Nat. Rev. Nephrol. 12, 414-425. doi: 10.1038/nrneph.2016.59

Rodriguez, L., Tu, C., Cheng, Z., Chen, T.-H., Bikle, D., Shoback, D., et al. (2005). Expression and functional assessment of an alternatively spliced extracellular $\mathrm{Ca}^{2+}$-sensing receptor in growth plate chondrocytes. Endocrinology 146, 5294-5303. doi: 10.1210/en.2005-0256

Rogers, K., Dunn, C., Conklin, R., Hadfield, S., Petty, B., Brown, E., et al. (1995). Calcium receptor messenger ribonucleic acid levels in the parathyroid glands and kidney of vitamin D-deficient rats are not regulated by plasma calcium or 1, 25-dihydroxyvitamin D3. Endocrinology 136, 499-504.

Ruat, M., and Traiffort, E. (2013). Roles of the calcium sensing receptor in the central nervous system. Best Pract. Res. Clin. Endocrinol. Metab. 27, 429-442. doi: 10.1016/j.beem.2013.03.001

Schlüter, B., König, B., Bergmann, U., Müller, F. E., and König, W. (1991). Interleukin 6-a potential mediator of lethal sepsis after major thermal trauma: evidence for increased IL-6 production by peripheral blood mononuclear cells. J. Trauma Acute Care Surg. 31, 1663-1670. doi: 10.1097/00005373-19911200000017

Shilo, V., Ben-Dov, I. Z., Nechama, M., Silver, J., and Naveh-Many, T. (2015). Parathyroid-specific deletion of dicer-dependent microRNAs abrogates the response of the parathyroid to acute and chronic hypocalcemia and uremia. FASEB J. 29, 3964-3976. doi: 10.1096/fj.15-274191

Singh, N., and Chakrabarty, S. (2013). Induction of CaSR expression circumvents the molecular features of malignant CaSR null colon cancer cells. Int. J. Cancer 133, 2307-2314. doi: $10.1002 /$ ijc. 28270

Singh, N., Liu, G., and Chakrabarty, S. (2013). Isolation and characterization of calcium sensing receptor null cells: a highly malignant and drug resistant phenotype of colon cancer. Int. J. Cancer 132, 1996-2005. doi: 10.1002/ijc. 27902

Steele, T., Kolamunnage-Dona, R., Downey, C., Toh, C.-H., and Welters, I. (2013). Assessment and clinical course of hypocalcemia in critical illness. Crit. Care 17:R106. doi: 10.1186/cc12756

Sulaiman, L., Juhlin, C. C., Nilsson, I. L., Fotouhi, O., Larsson, C., and Hashemi, J. (2013). Global and gene-specific promoter methylation analysis in primary hyperparathyroidism. Epigenetics 8, 646-655. doi: 10.4161/epi.24823

Tennakoon, S., Aggarwal, A., and Kállay, E. (2016). The calcium-sensing receptor and the hallmarks of cancer. Biochim. Biophys. Acta 1863(6 Pt B), 1398-1407. doi: 10.1016/j.bbamcr.2015.11.017.

Thomas, P. G., Dash, P., Aldridge, J. R., Ellebedy, A. H., Reynolds, C., Funk, A. J., et al. (2009). The intracellular sensor NLRP3 mediates key innate and healing responses to influenza A virus via the regulation of caspase-1. Immunity 30, 566-575. doi: 10.1016/j.immuni.2009.02.006

Thomée, C., Schubert, S. W., Parma, J., Lê, P. Q., Hashemolhosseini, S., Wegner, M., et al. (2005). GCMB mutation in familial isolated hypoparathyroidism with residual secretion of parathyroid hormone. J. Clin. Endocrinol. Metab. 90, 2487-2492. doi: 10.1210/jc.2004-2450

Thorleifsson, G., Holm, H., Edvardsson, V., Walters, G. B., Styrkarsdottir U., Gudbjartsson, D. F., et al. (2009). Sequence variants in the CLDN14 gene associate with kidney stones and bone mineral density. Nat. Genet. 41, 926-930. doi: 10.1038/ng.404
Toka, H. R., Pollak, M. R., and Houillier, P. (2015). Calcium sensing in the renal tubule. Physiology (Bethesda) 30, 317-326. doi: 10.1152/physiol.00042.2014

Tomar, N., Bora, H., Singh, R., Gupta, N., Kaur, P., Chauhan, S. S., et al. (2010). Presence and significance of a R110W mutation in the DNA-binding domain of GCM2 gene in patients with isolated hypoparathyroidism and their family members. Eur. J. Endocrinol. 162, 407-421. doi: 10.1530/EJE-09-0303

Toribio, R. E., Kohn, C. W., Capen, C. C., and Rosol, T. J. (2003). Parathyroid hormone (PTH) secretion, PTH mRNA and calcium-sensing receptor mRNA expression in equine parathyroid cells, and effects of interleukin (IL)-1, IL-6, and tumor necrosis factor-alpha on equine parathyroid cell function. J. Mol. Endocrinol. 31, 609-620. doi: 10.1677/jme.0.0310609

Toribio, R. E., Kohn, C. W., Chew, D. J., Sams, R. A., and Rosol, T. J. (2001). Comparison of serum parathyroid hormone and ionized calcium and magnesium concentrations and fractional urinary clearance of calcium and phosphorus in healthy horses and horses with enterocolitis. Am. J. Vet. Res. 62, 938-947. doi: 10.2460/ajvr.2001.62.938

Varshney, S., Bhadada, S. K., Sachdeva, N., Arya, A. K., Saikia, U. N., Behera, A., et al. (2013). Methylation status of the CpG islands in vitamin D and calciumsensing receptor gene promoters does not explain the reduced gene expressions in parathyroid adenomas. J. Clin. Endocrinol. Metab. 98, E1631-E1635. doi: 10.1210/jc.2013-1699

Vezzoli, G., Scillitani, A., Corbetta, S., Terranegra, A., Dogliotti, E., Guarnieri, V., et al. (2011). Polymorphisms at the regulatory regions of the CASR gene influence stone risk in primary hyperparathyroidism. Eur. J. Endocrinol. 164, 421-427. doi: 10.1530/EJE-10-0915

Vezzoli, G., Scillitani, A., Corbetta, S., Terranegra, A., Dogliotti, E., Guarnieri, V., et al. (2015). Risk of nephrolithiasis in primary hyperparathyroidism is associated with two polymorphisms of the calcium-sensing receptor gene. J. Nephrol. 28, 67-72. doi: 10.1007/s40620-014-0106-8

Vezzoli, G., Terranegra, A., Aloia, A., Arcidiacono, T., Milanesi, L., Mosca, E., et al. (2013). Decreased transcriptional activity of calcium-sensing receptor gene promoter 1 is associated with calcium nephrolithiasis. J. Clin. Endocrinol. Metab. 98, 3839-3847. doi: 10.1210/jc.2013-183

Villarroel, P., Villalobos, E., Reyes, M., and Cifuentes, M. (2014). Calcium, obesity, and the role of the calcium-sensing receptor. Nutr. Rev. 72, 627-637. doi: $10.1111 /$ nure. 12135

Yamada, Y., Endo, S., and Inada, K. (1996). Plasma cytokine levels in patients with severe burn injury-with reference to the relationship between infection and prognosis. Burns 22, 587-593. doi: 10.1016/S0305-4179(96)00052-6

Yao, J. J., Bai, S., Karnauskas, A. J., Bushinsky, D. A., and Favus, M. J. (2005). Regulation of renal calcium receptor gene expression by 1, 25dihydroxyvitamin D3 in genetic hypercalciuric stone-forming rats. J. Am. Soc. Nephrol. 16, 1300-1308. doi: 10.1681/ASN.2004110991

Yi, H. S., Eom, Y. S., Park, I. B., Lee, S., Hong, S., Jüppner, H., et al. (2012). Identification and characterization of C106R, a novel mutation in the DNA-binding domain of GCMB, in a family with autosomal-dominant hypoparathyroidism. Clin. Endocrinol. (Oxf). 76, 625-633. doi: 10.1111/j.13652265.2011.04256.x

Yun, F. H., Wong, B. Y., Chase, M., Shuen, A. Y., Canaff, L., Thongthai, K., et al. (2007). Genetic variation at the calcium-sensing receptor (CASR) locus: implications for clinical molecular diagnostics. Clin. Biochem. 40, 551-561. doi: 10.1016/j.clinbiochem.2006.12.011

Zaloga, G. P. (1992). Hypocalcemia in critically ill patients. Crit. Care Med. 20, 251-262. doi: 10.1097/00003246-199202000-00014

Zivin, J. R., Gooley, T., Zager, R. A., and Ryan, M. J. (2001). Hypocalcemia: a pervasive metabolic abnormality in the critically ill. Am. J. Kidney Dis. 37, 689-698. doi: 10.1016/S0272-6386(01)80116-5

Conflict of Interest Statement: The authors declare that the research was conducted in the absence of any commercial or financial relationships that could be construed as a potential conflict of interest.

Copyright (c) 2016 Hendy and Canaff. This is an open-access article distributed under the terms of the Creative Commons Attribution License (CC BY). The use, distribution or reproduction in other forums is permitted, provided the original author(s) or licensor are credited and that the original publication in this journal is cited, in accordance with accepted academic practice. No use, distribution or reproduction is permitted which does not comply with these terms. 